\title{
Māori Intellectual Property Rights and the Formation of Ethnic Boundaries
}

\author{
Toon van Meijl*
}

\begin{abstract}
This article questions and contextualizes the emergence of a discourse of intellectual property rights in Māori society. It is argued that Māori claims regarding intellectual property function primarily to demarcate ethnic boundaries between Māori and non-Māori. Māori consider the reinforcement of ethnic boundaries necessary since they experience their society and distinctive way of life as endangered both by the foreign consumption or misappropriation of aspects of their authentic cultural forms and by the intrusion of foreign cultural elements. Following Simon Harrison (1999) it is argued that the first threat is often represented as an undesired form of cultural appropriation, piracy or theft, while the second threat is viewed as a form of cultural pollution. This argument is elaborated with a case-study of each so-called danger, namely a claim regarding native flora and fauna submitted to the Waitangi Tribunal, which is considered as an example of resistance against cultural appropriation, and the increasing hostility of Māori to foreign interest and research in Māori culture and society, which is analysed as an example of opposition to putative pollution.
\end{abstract}

Over the past decade, the cultural renaissance of the New Zealand Māori has expanded into the legal regime of intellectual property rights. Māori people have not simply become more conscious and more proud of their cultural heritage, but their cultural traditions and the knowledge associated with them are increasingly cast as property of which the indigenous people of Aotearoa are the intellectual owners. Worldwide the discourse of intellectual property rights rapidly proliferated among indigenous peoples in the course of the 1990s. As early as 1991 this resulted a New Zealand Māori claim to the Waitangi Tribunal regarding indigenous forests and seven species of flora and fauna that are unique to New Zealand, namely the kūmara (sweet potato), pōhutukawa (New Zealand Christmas

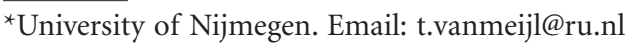


tree), koromiko (shrubs), puawānanga (native climbing plant), pūpū harakeke (flax snail), tuatara (reptile like a large lizard), and the kererū (wood pigeon). It was not until the late 1990s, however, that the concept of intellectual property rights began to more broadly refer to the protection of Māori heritage at large. In this article I argue that these more recent Māori discourses of cultural and intellectual property may be considered a sign of protest against the neglect of indigenous knowledge and associated traditions in the colonial past, while they also evoke a political struggle for indigenous autonomy. A function of the new, broader meaning of intellectual property rights is therefore the demarcation of ethnic boundaries between Māori and non-Māori.

The first intellectual property claim that received abundant attention in the media was the objection of Māori to the Danish company of LEGO toys when in 2001 it released on the market its Bionicle game in which Māori words, names, and concepts are used. Several Māori groups appeared unhappy with this use-in their view, abuse - of traditional names and concepts, and forced LEGO to stop using Māori words for its hi-tech toys. ${ }^{1}$ Māori challenges to LEGO’s use of Māori words and names have subsequently inspired many Māori groups and individuals to speak out against the use of Māori concepts in non-Māori domains or, alternatively, when they are deployed for purposes that deviate from their original meaning. Thus, a restaurateur in Amsterdam was persuaded to change the name of his new premise, which he had branded Moko, referring to Māori tattoo designs. Similarly, Māori express their strong disapproval when non-Māori people, including celebrities such as the singer Robbie Williams and the former world heavyweight champion in boxing Mike Tyson, wear a Māori tattoo and indicate they have no knowledge of, let alone sympathy with, the indigenous population of New Zealand. Likewise, the performance of the haka, a posture dance that has become famous around the world because it is carried out by the All Blacks (the national rugby team) before every test match, is condemned when staged by, for example, the Spice Girls during a holiday on Bali or by 100 scantily clad girls for a British television beer commercial. Indeed, nowadays Māori voices of protest are raised immediately when cultural symbols and expressions such as Māori moko and the haka are used for decoration or entertainment. Losing their original cultural meaning and significance in the new context is deplored and therefore discouraged. When non-Māori are urged to refrain from using anything of Māori origin, this appeal is increasingly justified with reference to the intellectual ownership of the names, concepts, designs, symbols, or expressions. Māori draw on the legal discourse of intellectual property, with the hope and expectation that it will enable them either to prohibit other people from using Māori symbols or to stipulate conditions severely restricting the use or exploitation of Māori cultural symbols.

This article aims to interpret, question, and contextualize Māori appeals to the concept of intellectual property rights. Over the past decade, it has become obvious that intellectual property rights, normally recognized for patents, copyrights, and trademarks only, cannot automatically be used for the protection of indigenous 
knowledge for a variety of reasons. Māori consider their cultural knowledge as their property because it is understood to have been transmitted over generations of Māori people; but legally, this transmission is precisely what makes it rather problematic: It implies that the indigenous heritage is much older than is allowed within the scope of intellectual property legislation ( 50 or 70 years). Indigenous expressions of knowledge cannot be ascribed to one identifiable inventor either, which is another requirement of conventional intellectual property legislation. ${ }^{2}$ In addition, indigenous claims to stop others from using their heritage are also contradictory to the purpose of intellectual property legislation that aims at making knowledge available in the public domain. ${ }^{3}$ These contradictions are further compounded by the expansion of the concept of intellectual property to cultural property as though the law would recognize originality in a broad sense, which it does not. ${ }^{4}$

Legal barriers to using intellectual property rights, however, do not stop Māori people from seeking support of this regime for the protection of their cultural heritage (i.e., by developing sui generis legislation). ${ }^{5}$ Continuing appeals to the legal regime of intellectual property rights, however, do raise the question regarding the function of the legal discourse in relation to Māori culture. The argument put forward here is that the notion of intellectual property rights is appealing less for reasons of material gain than because it supports Māori attempts to mark out boundaries around their social, cultural, and symbolic practices to regain their indigenous autonomy and differentiate themselves from mainstream New Zealand society. In my view Māori consider the specific and explicit delineation of cultural and ethnic boundaries necessary because they experience their society and distinctive way of life as endangered both by the intrusion of foreign cultural elements and the foreign consumption or misappropriation of aspects of their authentic cultural forms. Following Harrison, it may be argued that the first threat is often represented as an undesired form of cultural pollution, whereas the second threat is viewed as a form of cultural appropriation, piracy, or theft. ${ }^{6}$ Both imageries are related in Māori discourse because a common rhetoric of intellectual property rights is employed to counter the perceived threats. ${ }^{7}$ In this article I elaborate this argument with a case-study of each so-called danger, namely the claim regarding native flora and fauna submitted to the Waitangi Tribunal, which I consider an example of resistance against cultural appropriation, and the increasing hostility of Māori to foreign interest and research in Māori culture and society, which I analyze as an example of opposition to so-called pollution.

\section{WAI $262^{8}$}

In 1988 a group of Māori elders gathered to discuss their common concern over the increasing depletion of native plants and animals, the ongoing destruction of ecosystems, and the gradual loss of traditional Māori knowledge (mātauranga Màori) associated with indigenous flora and fauna. They formulated a claim to 
the Waitangi Tribunal ${ }^{9}$ that was filed in 1991 and amended in 1997, but submissions were not completed until the year 2006; it has become known as claim Wai 262. The claim was submitted by six tribes from various regions in New Zealand: Ngāti Kuri, Ngāti Wai, Te Rarawa, Ngāti Kahungunu, Ngāti Porou, and Ngāti Koata. The main aim of the claim is to protect Māori cultural and intellectual heritage rights in relation to indigenous flora and fauna and their traditional knowledge, customs, and practices related to it.

The claim is founded on the rights mentioned in article 2 of the Treaty of Waitangi, which guaranteed to Māori "the full exclusive and undisturbed possession of their Lands and Estates Forests Fisheries and other properties which they may collectively or individually possess." The crucial phrase in the Māori version of this clause is centered around Māori chieftainship, or te tino rangatiratanga, on the basis of which Māori people claim the right to self-determination. In the Statement of Claim Wai 262, it is also declared that Māori people "have been and are prejudicially affected by the actions and omissions of the Crown and its representatives in denying te tino rangatiratanga." Chieftainship in this context is further specified as the right to determine, participate in, benefit from, and make decisions about "the protection, control, conservation, management, treatment, propagation, sale, dispersal, utilisation and restrictions upon the use of indigenous flora and fauna ... the genetic resources therein me o ratou taonga katoa (and all their treasures)...." The concept of taonga in the Māori language, and therefore also in this claim, refers to both material and nonmaterial, tangible and intangible, dimensions of a tribal group's estate. Hence, it is mentioned in the Statement of Claim that taonga include, but are not limited to knowledge, carvings, sacred sites, Māori medicines, biodiversity, genetics, Māori cultural images, symbols and designs, their use and development, and also their associated indigenous, cultural and customary heritage rights.

The Statement of Claim contends that the rights that Māori people derive from the Treaty of Waitangi and that relate to their cultural heritage have been violated since Māori have never been involved in decision-making processes about technological developments, such as conventional plant breeding and genetic engineering. These techniques are increasingly applied to several native plant species in intergovernmental research programs. However, Māori people have never been consulted about Crown policies such as patenting and protection. Consequently, they claim that their proprietary interests in native flora and fauna have been neglected in the past and continue to be neglected in the present. Protection policies and the disposal of patents to multinational companies without Māori consent have placed indigenous flora and fauna beyond Māori access and fail to acknowledge the cultural role of the Māori people as guardians of New Zealand's native species. International scientific organizations and overseas commercial companies can collect native species through Crown export trade policies, but it is argued in the Statement of Claim that the result simply is that Māori suffer the loss of access to indigenous plants and animals for traditional purposes. 
These general grievances of the claimants are clarified in the Statement of Claim through a discussion of several particular species of flora and fauna, especially in relation to specific Crown actions and inactions affecting the species. ${ }^{10}$ As mentioned before, claimants focus their concerns on various species of indigenous forest timber, four species of flora, and three species of fauna. All species are regarded as an integral part of Te Wao Nui a Tane (The Great Forest of Tane), which refers to the natural habitat of the species that are subject of the claim. In addition, the native species are considered gifts from Papatuanuku (the Earth-Mother). As such, they fall under Māori guardianship, but because this is culturally expected to be exercised by different Māori tribes, the claim has been submitted by six different tribal groups.

\section{THE (MIS-)APPROPRIATION OF MĀORI CULTURAL HERITAGE}

In view of the magnitude and scope of claim Wai 262, it is taking the Waitangi Tribunal a long time to complete investigations. In 1997 some hearings took place, but the completion of traditional evidence of the six tribes was subsequently postponed until 2006. In the meantime several research reports have also been commissioned by the tribunal, but the final report is still pending. A comparative analysis of the research reports illustrates that the legal discourse of intellectual property rights serves to depoliticize the underlying sociopolitical debate about the unequal relationship between Māori and the dominant European majority in New Zealand. A political struggle about power and control clearly influences the juridical discussion about the property rights of Māori culture between lawyers. Thus, David Williams offers strong support of the Māori claim by expanding the evidence offered by the claimants in their Statement of Claim. ${ }^{11}$ At the same time, he criticizes the strictly legal perspective on the claim offered by Peter Dengate Thrush, ${ }^{12}$ who has assessed Wai 262 in light of international legislation in the field of intellectual property rights, and who concluded skeptically that "modern intellectual property doctrines may be of little relevance" to the claim. ${ }^{13}$ Although the findings of Dengate Thrush have been criticized on political grounds, his legal discussion provides a broad perspective on the significance of intellectual property legislation for Wai 262.

Dengate Thrush ${ }^{14}$ doubts whether the species to which the claim refers may be patented for two different reasons. First, he argues that current intellectual property thinking considers those species as all plants and animals to be in the public domain. Second, and more importantly, he draws attention to the fact that patents are only awarded when common goods are transformed into a new product. In such cases patents refer either to the new product or to the new method of transformation. Thus, the species mentioned in the claim cannot be patented, only new species or new methods of using or processing the species.

Obviously, claim Wai 262 is directed toward granting intellectual property rights in relation to the species of indigenous flora and fauna, but to a large extent it 
may be read as an objection to the absence of control of the processes affecting the plants and animals. Here, too, however, Dengate Thrush ${ }^{15}$ plays the devil's advocate. He explicitly rejects the allegation, for example, that the Crown deliberately allowed numerous species of kumara to be sent overseas, by referring to the common sense knowledge that for hundreds of years plants and animals worldwide were regarded as common property. This is embedded in the International Undertaking on Plant Genetic Resources passed by the United Nations Food and Agricultural Organisation in $1983 .^{16}$

In conclusion, Dengate Thrush advances the view that "intellectual property law is an inappropriate vehicle for the protection of indigenous peoples' rights." ${ }^{17}$ He draws attention to the ambivalence of the claim, referring to intellectual property rights as well as proprietary rights grounded in the Treaty of Waitangi, resulting in the request for total control. Skepticism about the first aspect of the claim is based on the lack of evidence that new species may be developed or that species may be used in an innovative manner, whereas the second aspect is doubtful because it remains unclear whether each species mentioned in the claim was under proprietary control at the time when the treaty was signed in 1840. It is important to emphasize that Dengate Thrush does not deny Māori rights to their legal property as protected by the Treaty of Waitangi. Dengate Thrush has only expressed his reservations about the evidence provided in the claim and the relevance of the intellectual property law paradigm to the desire of the Mãori to regain control about everything that they consider "their own." 18

Indeed, a close analysis of Wai 262 leaves the impression that Māori people appeal to intellectual property rights, not primarily to secure the exclusive rights to a limited number of biological resources, but mainly to prevent their commercialization by non-Māori and also to stop the (mis-)appropriation of their heritage by others. Thus, intellectual property rights seem to be used partly as a vehicle to sharpen the boundaries between Māori and non-Māori, which cannot be understood independently of the Māori quest for sovereignty. Against the background of dispossession and disenfranchisement in the colonial era, Māori people consider it increasingly important to define mine and thine, and for that purpose each available strategy is applied, including the legal regime of intellectual property legislation. In view of the growing relevance of intellectual property rights in the international arena of indigenous peoples, Māori people have also begun exploring this domain to recover their lost ground, both literally and symbolically. The metaphorical meaning of the intellectual property of the plants and animals that form the subject of claim Wai 262 is the unequivocal political message that Māori people no longer accept that aspects of their cultural heritage be used by others for purposes that may be irreconcilable with Māori intentions.

The ramification of this strategy becomes particularly evident in comparison with the parallel tendency of setting hurdles for the access of outsiders to Māori society for research purposes. The admission of nonindigenous people for reasons of study is increasingly complicated because they are under suspicion of possibly 
alienating essential elements of Māori society that Māori people consider as their own. In addition, foreign interest is believed to endanger the integrity and propriety of Māori culture, which is progressively protected as the intellectual property of the indigenous people of New Zealand. The Māori lawyer Aroha Mead, ${ }^{19}$ for example, discusses the creation of Māori Centres for Research Excellence at New Zealand universities as an important attempt to reclaim Māori research, which she justifies with reference to intellectual property legislation. Thus, the obstruction of external interest in indigenous culture is not only justified as the necessary preservation of cultural purity, but it is also linked to the campaign against the possible loss of cultural aspects from Māori society, which is legitimized as the protection of their cultural and intellectual ownership. ${ }^{20}$

The paradoxical relationship between the two ostensibly different political strategies of checking and balancing - on the one hand, the foreign consumption and, on the other hand, the foreign intrusion of Māori cultural elements and forms-is that both are increasingly justified with reference to the protection of Māori intellectual property rights. An important implication of the discourse about intellectual property rights is therefore that cultural boundaries are reinforced between insiders and outsiders, between authentic and inauthentic. In the next section I further elaborate that following the growing resistance from Māori to research into their society, the exchange of cultural symbols across ethnic boundaries is hampered.

\section{OPEN VERSUS CLOSED RESEARCH}

Over the past 40 years, it has become increasingly difficult for non-Māori to conduct research into Māori society. In view of the colonial legacy of New Zealand it cannot be surprising that many Māori people are reluctant to accept views of their society that are authored by outsiders, but it is unprecedented that Māori represent research into their society by non-Māori more and more as an infringement of their intellectual property. ${ }^{21}$ For that reason, too, it is advocated widely that research into things Māori must only be conducted by Māori. In this context it is interesting to discuss recent attempts to substantiate Māori resistance against ethnographic and historical research into their society by outsiders. ${ }^{22}$

Decolonizing Methodologies (1999) by Linda Tuhiwai Smith is the most controversial book invalidating research by outsiders interested in indigenous peoples' societies. In this book Smith argues that acquiring knowledge about indigenous peoples, as distinct from what they narrate about themselves, is a way of colonizing them and amounts therefore to imperialism. Her argument is partly derived from the view of Foucault and Said that knowledge and representation may be used as an instrument of power. Smith's interpretation of this point, however, is that the only valid knowledge about colonized societies, such as those of indigenous peoples, is the knowledge that indigenous peoples produce about them- 
selves, because knowledge of indigenous peoples developed by outsiders may only serve the purpose of oppression. Indigenous peoples are therefore to be given the monopoly over and total control of their representation. Thus, Smith advocates the rigorous replacement of the so-called colonizing methodology of research by a decolonized methodology that only allows indigenous peoples to speak for themselves.

The final chapter of the book provides suggestions for the implementation of decolonized research. The main recommendation is to check and consult with people to understand their thoughts and behavior in their own environment. ${ }^{23}$ This conclusion is so obvious that it also reveals that the crux of the book revolves around the ethnicity of the researcher. Underlying the distinction between colonized and decolonized research is a dichotomy between outsiders andindigenous—insiders. This division involves a caricature of non-Māori researchers as well as a naïve idealization of Māori academics and their work. Furthermore, it excludes Māori scholars from being internally critical while it also pressurizes them not to write about non-Māori. Consequently, Smith's proposition that indigenous discourses of Māori society are to be privileged above research from outsiders must be deconstructed, especially because most cases refer to a small group of advantaged academics, which pretends to be representative because they have a vested interest in the arguments that are at stake in a contested field of representation. ${ }^{24}$

In this context it is important to make explicit that Māori society is a hierarchical society in which certain groups are traditionally advantaged above others. The tribal division of status and prestige continues to linger on in contemporary society, reflected among other things in higher education, better jobs, and higher incomes for a small group of people that is not infrequently of aristocratic descent. ${ }^{25}$ In view of the segregation of Māori society, it is essential to leave the whole discursive field of analysis open to interventions from every direction; and therefore, too, non-Māori scholars cannot be expected to write exclusively for their informants. In this context it is crucial to ask, "Which informants?" To which sociopolitical rank do they belong? In view of these questions, no voices should be silenced in this multisided debate, inside or outside. Contributions to the representation of Māori society should be judged primarily on their analytical merits rather than their origins.

Recently, several other attempts have been made to demonstrate that Māori knowledge is fundamentally different from European knowledge. Roberts and Wills, ${ }^{26}$ for example, have argued that the distinctive template for Māori knowledge is constituted by genealogies (whakapapa), which provide "the cognitive framework for ordering and classifying the entire phenomenal world, and also for developing theories about knowledge." 27 The connection between genealogy and knowledge also illustrates the link between Māori conceptions of knowledge and claims of Māori cultural and intellectual ownership. This link is further compounded by the view that whakapapa guide the disclosure of knowledge to those not yet familiar with it. In that context, a distinction is made between "open knowl- 
edge" accessible to all and "closed knowledge" restricted to "a chosen few." 28 This hierarchy of knowledge makes knowledge vulnerable to the active repression of dissonant expressions and unorthodox ideas that may be associated with differences in power and influence. This flip side of the distinction between open and closed knowledge within Māori society makes it interesting to draw an analogy with the distinction between colonizing and decolonizing methodologies made by Linda Smith. ${ }^{29}$

The notion of whakapapa has also come to play a crucial role in the increasingly politicized discussion about research into Māori history. In 1991 the Māori historian Joseph Pere set the tone for the debate with a so-called Māori perspective on the practice of Māori history writing and the related question of who could do so. He challenged the right of non-Māori historians to engage in Māori historiography, because in his view they lack the genealogical connections necessary to understand the most important values, beliefs, and attitudes that are central in Māori society in past and present. To avoid the risk of joining the ranks of the "historical imperialists" of the nineteenth century, he stipulated the condition of approval by Māori elders, the guardians of the ancestors, for all research into the sacred past of the Māori. ${ }^{30}$ This view also implies a full and final closure of research into the past and the present of Māori society. ${ }^{31}$

Another crucial contribution to the debate on the differences between internal and external perspectives on the Māori past and present has recently been made by the Māori scholar Te Maire Tau. ${ }^{32} \mathrm{He}$ also outlines a vision of traditional Māori knowledge (mätauranga Māori) as a separate way of knowing in contrast with the western worldview. In his view, too, màtauranga Māori is incapable of comprehension or criticism by the western canons of epistemology and methodology, because it is authorized and sanctioned by the ancestors. This assumption does not only permit the possibility that màtauranga Māori is taken as the sole measure of the Māori past and the Māori present, but at the same time it allows for Māori claims of cultural and intellectual ownership of knowledge.

Both Pere's and Tau's reflections on the differences between Māori and European knowledge systems and the implications for Māori historiography have already led to interesting reflections by New Zealand historians. Ballara ${ }^{33}$ has analyzed this debate in terms of the classic dilemma between "emic" and "etic" perspectives in cross-cultural research. Reilly made the insightful remark that the Māori historians discussed above are not simply indigenizing Māori history writings, but "they are asserting a claim of tino rangatiratanga or sovereignty over history about the Māori of Aotearoa." 34 This statement highlights the connection between these radical attempts to keep ethnography and historiography about Māori for Māori, on one hand, and Māori claims of cultural and intellectual ownership of knowledge, on the other. It draws attention to the underlying motivation behind the tendency to close Māori research for non-Māori, which effectively functions to create and reinforce ethnic boundaries between Māori and European scholars. This highlights the essential meaning of the recent emergence of the discourse of cul- 
tural and intellectual property rights in Māori society that not only parallels the closure of Māori research for non-Māori, but in terms of which it is also justified and legitimized.

\section{ETHICAL IMPURITY?}

The role of ethnography and historiography in the colonization of non-western peoples has been the subject of scholarly reflection for a long time. ${ }^{35}$ It is no longer disputed that both academic disciplines made important contributions to the colonial project of classifying, representing, and ruling subject populations. This unequivocal conclusion, however, does not imply that the encounter between foreign researchers and colonized populations can be reduced to a relationship between oppressor and oppressed. Many historians and ethnographers have been involved in a serious challenge of the assumption of colonial superiority. The interaction between both sides of the colonial encounter was therefore more complex, and not all documentations of indigenous worldviews can be rejected as contaminated by colonialism. ${ }^{36}$ In addition, it is ironic that today many indigenous peoples, including Māori, make good use of historical and ethnographic records drawn up by foreign researchers to substantiate, for example, claims about violations of the Treaty of Waitangi. Despite this ambivalent relationship of Māori to research into their society by non-Māori, the tendency toward external attention or curiosity is one of increasing hostility.

A variety of strategies is deployed to regulate research by outsiders to avoid the misappropriation of aspects of indigenous societies. The most important mechanism in this context is the organization of procedures to ensure that academic research meets certain ethical guidelines. All research that takes place under the auspices of a New Zealand university or in which academics affiliated to a local university are involved now must be approved of by ethical committees in which Māori are strongly represented. Just recently, the University of Otago even decided to consult the local Ngai Tahu tribe concerning, not only research involving Māori, but all research undertaken by employees of the university and its affiliates. ${ }^{37}$ The ethics of academic research are generally characterized by ambiguities and dilemmas, however, which makes ethical procedures and the implementation of ethical codes vulnerable to ethnic politics. ${ }^{38}$ Some of my students, for example, who aimed to become advocates of indigenous politics, met with great opposition from Māori delegates on ethical committees at New Zealand universities, who simply applied bureaucratic procedures to discourage them to proceed with their pilot projects. Thus, intellectual property claims are extended to all types of research, including noncommercial studies.

Following Greaves ${ }^{39}$ and Strathern, ${ }^{40}$ I wish to avoid all possible misunderstandings about any implications of my argument suggesting that intellectual property legislation may not constitute an appropriate vehicle for the reorganization of eth- 
nographic and historical research into Māori society by non-Māori. Inevitably, Māori will redirect research into their society and prevent the commercialization of aspects of their culture by outsiders. At the same time, however, it might be subject of debate whether references to intellectual property rights regarding the results of ethnographic and historical research are the most productive in this context because they entail the reinforcement of ethnic boundaries between Māori and non-Māori.

\section{CONCLUSION}

In this article I have analyzed Māori discourses of intellectual property rights as political strategies to demarcate ethnic boundaries between Māori and non-Māori. This argument has enabled me to discuss two discourses under the same rubric, namely Māori attempts to prevent the (mis-) appropriation of aspects of their cultural heritage by outsiders, on one hand, and Māori attempts to prevent research into their society by outsiders, on the other hand. Both strategies result in the reinforcement of ethnic boundaries, but there is a crucial difference between them: The first boundary is drawn because Māori culture is assumed to be threatened by the foreign appropriation and exploitation of indigenous cultural forms, whereas the second is put up to avoid interventions in Māori culture through the intrusion of foreign researchers. ${ }^{41}$

The first practice I have illustrated with a case-study of Wai 262, a claim submitted to the Waitangi Tribunal regarding the protection of indigenous flora and fauna. Māori claim to be the cultural owners of the biological species mentioned in the claim as well as the intellectual owners of all knowledge associated with the species concerned and that may be used for the development of, for example, new medicines. Interestingly, however, the evidence regarding the possible exploitation of indigenous flora and fauna is rather limited so that other motives behind the claim must be assumed. These I have deconstructed as political and strategic to secure Māori culture at large against the use by non-Māori. This also explains the increasing references to Māori intellectual property rights in New Zealand as mentioned and discussed in the beginning of this article. Māori people are sick and tired of the use of their culture or aspects thereof by others who in some situations make some money with the commercialization of Māori cultural forms. ${ }^{42}$ In consequence, they now seek to secure legal rights to their cultural and intellectual property, but the result is that the meaning of this juridical regime has been stretched beyond its limits. In practice, the discourse of intellectual property rights when applied to prevent the misappropriation of Māori cultural aspects functions chiefly to reinforce ethnic boundaries between Māori and non-Māori by employing a rhetoric of cultural appropriation, piracy, or theft ${ }^{43}$ and ending as far as possible the external movement of virtually anything originating in Māori society. In a letter to the editor of a national newspaper, some- 
one even expressed her opposition to non-Māori "appropriating" the Māori language, which was likened to the land thefts in the nineteenth century (The Dominion Post, 6-3-2003). It illustrates what some Māori appeals to intellectual property rights may entail, at least in ideology: the end of all cross-cultural exchanges and ultimately even of all communication.

I have illustrated the second practice with an analysis of Māori attempts to close their society to outside researchers. Naturally, this discussion extends from the first discourse that seeks to stop the flow of cultural elements out of Māori society. This makes it simultaneously necessary to stop the interference of foreign researchers, who after all are offered the opportunity to extract cultural elements from Māori society when allowed to cross the boundaries and conduct their research. The barriers constructed to research by outsiders in Māori society are legitimized in terms of a discourse about the protection of Māori knowledge systems that become desacralized if not polluted by foreign research because non-Māori have no genealogical connections with Māori.

The common denominator of both practices is the division of the world into two radically distinct kinds of people: Māori and non-Māori, insiders and outsiders. ${ }^{44}$ This distinction, however, is drawn in two different ways. In the first discourse insiders are represented as those with a Māori whakapapa and therefore entitled to the use, reproduction, and exploitation of Māori traditions, customs, and beliefs, while outsiders are excluded from these rights. In the second discourse, insiders also have genealogical connections with Māori ancestors; and for that reason they may be considered as blessed with a commitment to uphold Māori traditions, customs, doctrines, and beliefs, while outsiders lack the guidance of the ancestral guardians and therefore must be considered as desecrating, impure, and inferior. In both cases Māori self-definition is accomplished in opposition to a potentially or actually threatening Other, which, however, is again constructed in two opposite ways, either as an extractive or exploitative Other for whom Māori culture has to be secluded, or as an expansionist or intervening Other whose intrusion has to be resisted. In sum, Māori people deploy a rhetoric of cultural and intellectual property rights to enclose themselves in boundaries against both the external piracy and the internal pollution of their culture.

\section{ENDNOTES}

1. Coombe and Herman, "Rhetorical Virtues: Property."

2. Brown, "Can Culture Be Copyrighted?"

3. Brown, Who Owns Native Culture?

4. Strathern, "Potential Property: Intellectual Rights," 23; and Property, Substance and Effect.

5. See Recht, this issue.

6. Harrison, "Cultural Boundaries."

7. Harrison, Fracturing Resemblances: Identity.

8. My discussion of the Wai 262 claim is based on the following sources: Solomon, "Intellectual Property Rights" and "The Wai 262 Claim"; Solomon and Watson, "The Waitangi Tribunal"; Wil- 
liams, Matauranga Māori and Taonga; and the Statement of Claim that was filed with the Waitangi Tribunal.

9. The Waitangi Tribunal examines Māori claims about violations of the Treaty of Waitangi that have prejudicially affected them. The Treaty of Waitangi is a pact between the Mãori and the British Crown that was signed in 1840. In the treaty the Māori ceded sovereignty in exchange for the possession of their lands and other resources.

10. See also Williams, Matauranga Māori and Taonga, 112-42.

11. Matauranga Māori and Taonga.

12. Indigenous Flora and Fauna.

13. Dengate Thrush, Indigenous Flora and Fauna, 61.

14. Indigenous Flora and Fauna, 53.

15. Indigenous Flora and Fauna, 54.

16. Dengate Thrush, Indigenous Flora and Fauna, 54.

17. Indigenous Flora and Fauna, 61.

18. See also Barclay, Mana Tuturu: Māori Treasures, 66-90.

19. "Understanding Māori Intellectual Property."

20. Compare Harrison, "Cultural Boundaries."

21. For example Mead, "Understanding Māori Intellectual Property."

22. For example Bishop, "Freeing Ourselves from Neocolonial," and Smith, "On Tricky Ground."

23. See also Smith, "Getting the Story Right."

24. Keesing, "Class, Culture, Custom."

25. Webster, Patrons of Māori Culture, Rata, "Late Capitalism and Ethnic."

26. "Understanding Māori Epistemology," 62.

27. See also Roberts, Haami, Benton, Satterfield, Finucane, Henare, and Henare, "Whakapapa as a Māori."

28. Roberts Haami, Benton, Satterfield, Finucane, Henare, and Henare, "Whakapapa as a Māori," 65.

29. Compare Munz, "Open and Closed Research."

30. Pere, "Hitori Māori," 45-46.

31. Reilly, "An Ambiguous Past," Ballara, "I riro I te hoko."

32. "Matauranga Māori as Epistemology."

33. "I riro I te hoko," 26.

34. "An Ambiguous Past," 20.

35. Guha and Spivak, Selected Subaltern Studies, Pels and Salemink, "Introduction: Five Theses," Thomas, Colonialism's Culture: Anthropology.

36. Brown, "Can Culture Be Copyrighted?" 200.

37. Rata and Openshaw, Public Policy and Ethnicity, 13.

38. Van Meijl, "Modern Morals in Postmodernity."

39. "Cultural Rights and Ethnography."

40. "Potential Property: Intellectual Rights," 26-29.

41. Harrison, "Cultural Boundaries;" see also Harrison, Fracturing Resemblances: Identity.

42. Compare Barclay, Mana Tuturu: Māori Treasures.

43. See also Harrison, "Identity as a Scarce."

44. See also Rata and Openshaw, Public Policy and Ethnicity.

\section{BIBLIOGRAPHY}

Ballara, Angela. "'I riro I te hoko': Problems in Cross-cultural Historical Scholarship." New Zealand Journal of History 34, no. 1 (2000): 20-33.

Barclay, Barry. Mana Tuturu: Māori Treasures and Intellectual Property Rights. Auckland, New Zealand: Auckland University Press, 2005. 
Bishop, Russell. "Freeing Ourselves from Neocolonial Domination in Research: A Kaupapa Māori Approach to Creating Knowledge." In The Sage Handbook of Qualitative Research, edited by Norman K. Denzin and Yvonna S. Lincoln, 3rd ed., 109-39. Thousand Oaks, CA: Sage Publications, 2005. First published in 1994.

Brown, Michael F. “Can Culture Be Copyrighted?” Current Anthropology 39, no. 2 (1998): 193-222.

Who Owns Native Culture? Cambridge, MA: Harvard University Press, 2003.

Coombe, Rosemary, and Andrew Herman. "Rhetorical Virtues: Property, Speech, and the Commons on the World Wide Web." Anthropological Quarterly 77, no. 3 (2004): 559-74.

Dengate Thrush, Peter. Indigenous Flora and Fauna of New Zealand. Waitangi Tribunal Research Series no. 1995/1. Wellington: Brooker's, 1995.

Greaves, Thomas C. "Cultural Rights and Ethnography." General Anthropology 1, no. 2 (1995): 1-6.

Guha, Ranajit, and Gayatri Chakravorty Spivak, eds. Selected Subaltern Studies. New York: Oxford University Press, 1988.

Harrison, Simon. “Cultural Boundaries.” Anthropology Today 15, no. 5 (1999): 10-13.

- Fracturing Resemblances: Identity and Mimetic Conflict in Melanesia and the West. New York: Berghahn Books, 2006.

"Identity as a Scarce Resource." Social Anthropology 7, no. 3 (1999): 239-51.

Keesing, Roger. "Class, Culture, Custom." In Melanesian Modernities, edited by Jonathan Friedman and James G. Carrier, 162-82. Lund, Sweden, and Bromley, England: Lund University Press and Chartwell-Bratt, 1996.

Mead, Aroha Te Pareake. “Understanding Māori Intellectual Property Rights.” Paper presented to the Inaugural Māori Legal Forum, October 10, 2002. Wellington: Victoria University of Wellington.

Meijl, Toon van. "Modern Morals in Postmodernity: A Critical Reflection on Professional Codes of Ethics." Cultural Dynamics 12, no. 1 (2000): 65-81.

Munz, Peter. “Open and Closed Research: Review of 'Decolonizing Methodologies' by Linda Tuhiwai Smith.” New Zealand Books 9, no. 5 (1999): 6.

Pels, Peter, and Oskar Salemink. "Introduction: Five Theses on Ethnography as Colonial Practice." History and Anthropology 8, no. 1 (1994): 1-34.

Pere, Joseph. "Hitori Māori." In The Future of the Past: Themes in New Zealand History, edited by Colin Davis and Peter Lineham, 29-48. Palmerston North: Department of History, Massey University, 1991.

Rata, Elizabeth. "Late Capitalism and Ethnic Revivalism, 'A New Middle Age?'” Anthropological Theory 3, no. 1 (2003): 46-64.

Rata, Elizabeth and Roger Openshaw, eds. Public Policy and Ethnicity: The Politics of Ethnic Boundary Making. Basingstoke: Palgrave Macmillan, 2006.

Reilly, Michael. “An Ambiguous Past: Representing Māori History." New Zealand Journal of History 19, no. 1 (1995): 19-39. 
Roberts, Roma Mere and Peter R. Wills. "Understanding Māori Epistemology: A Scientific Perspective" In Tribal Epistemologies: Essays in the Philosophy of Anthropology, edited by Helmut Wautischer, 43-71. Aldershot, England: Ashgate Publishing, 1998.

Roberts, Mere, Brad Haami, Richard Benton, Terre Satterfield, Melissa L. Finucane, Mark Henare and Manuka Henare. "Whakapapa as a Māori Mental Construct: Some Implications for the Debate over Genetic Modification of Organisms.” The Contemporary Pacific 16, no. 1 (2004): 1-28.

Smith, Linda Tuhiwai. Decolonizing Methodologies: Research and Indigenous Peoples. London, and Dunedin, New Zealand: Zed Books and University of Otago Press, 1999.

."Getting the Story Right-Telling the Story Well: Indigenous Activism-Indigenous Research." In Pacific Genes and Life Patents: Pacific Indigenous Experiences and Analysis of the Commodification and Ownership of Life, edited by Aroha T.R. Mead and Steven Ratuva, 74-81. Wellington: Call of the Earth/Llamado de la Tierra and Institute of Advanced Studies, United Nations University, 2007. Available at http://www.ias.unu.edu/sub_page.aspx?catID=97\&dd1ID=229 (accessed 25 October, 2009).

. "On Tricky Ground: Researching the Native in the Age of Uncertainty." In The Sage Handbook of Qualitative Research, edited by Norman K. Denzin and Yvonna S. Lincoln, 3rd ed., 85-107. Thousand Oaks: Sage Publications, 2005. First published in 1994.

Solomon, Maui. "Intellectual Property Rights and Indigenous Peoples Rights and Obligations." Motion Magazine, April 22, 2001, 1-16.

. "The Wai 262 Claim: A Claim by Māori to Indigenous Flora and Fauna: Me o Ratou Taonga Katoa." In Waitangi Revisited: Perspectives on the Treaty of Waitangi, edited by Michael Belgrave, Merata Kawharu, and David Williams, 213-32. Melbourne: Oxford University Press, 2005.

Solomon, Maui, and Leo Watson. “The Waitangi Tribunal and the Māori Claim on their Cultural and Intellectual Heritage Rights Property.” Cultural Survival Quarterly 24, no. 2 (2001): 46-50.

Strathern, Marilyn. "Potential Property: Intellectual Rights and Property in Persons.” Social Anthropology 4, no. 1 (1996): 17-32.

Property, Substance and Effect: Anthropological Essays on Persons and Things. London: Athlone Press, 1999.

Tau, Te Maire. "Matauranga Māori as Epistemology." In Histories, Power and Loss: Uses of the Past-A New Zealand Commentary, edited by Andrew Sharp and Paul McHugh, 61-73. Wellington: Bridget Williams, 2001.

Thomas, Nicholas. Colonialism's Culture: Anthropology, Travel and Government. Cambridge: Polity Press, 1994.

Webster, Steven. Patrons of Māori Culture: Power, Theory and Ideology in the Mãori Renaissance. Dunedin: Otago University Press, 1998.

Williams, David. Matauranga Māori and Taonga: The Nature and Extent of Treaty Rights Held by Iwi and Hapu in Indigenous Flora and Fauna, Cultural Heritage Objects, Valued Traditional Knowledge. Wellington, New Zealand: Waitangi Tribunal, 2001. 